\title{
Indiana University School of Social Work: 90 Years of Professional Education
}

\author{
Monique Busch \\ Gerald T. Powers \\ David Metzger \\ Cyrus S. Behroozi \\ Sheldon Siegel \\ Barry R. Cournoyer
}

\begin{abstract}
In this invited article, the authors review the history and development of the Indiana University School of Social Work from its origin in 1911 as a small department to its current status as a large organization offering educational programs to nearly 900 students on five campuses. One of the nation's oldest, it is the only school to offer the full continuum of social work education from the associate through the doctoral levels. In many respects, the evolution of the School mirrors the experiences of other schools and departments of social work. As such, the article may be enlightening to those interested in the history of social work education in this country.
\end{abstract}

Keywords: History, Indiana University, social work, education

$O^{2}$ chools of social work mirror the social, political, economic, and academic contexts within which they evolve. As Levy (1968) suggests, "What is true of the history of man in general is true of the history of social work education, the past and present are manifest in each other" (p. 5). The Indiana University School of Social Work is no exception.

Founded in 1911 as the Social Service Department, the School has operated continuously for 90 years (Rogers, 1983). On the occasion of this $90^{\text {th }}$ anniversary (1911-2001) celebration, it seems fitting that we reflect upon the School's history and the events that shaped, and at times, been shaped by its existence.

Social workers well know that attempts to capture history require difficult choices. We have to decide what and how much detail to include, what perspectives to adopt, and which themes to recognize or emphasize. Writing history invariably involves construction as well as recollection of knowledge. This brief review of the 90-year history of the School reflects both choices and constructions. We could not

Monique Busch, M.S.W. is a doctoral student; Gerald T. Powers, Ph.D. is Professor; David Metzger, M.A. is Associate Professor Emeritus; Cyrus S. Behroozi, Ph.D. is Profesor Emeritus and former Associate Dean; Sheldon Siegel, Ph.D. is Professor Emeritus and former Dean; and Barry R. Cournoyer, D.S.W., L.C.S.W. is Professor, Indiana University of Social Work, Indianapolis.

Copyright@ 2001 Advances in Social Work Vol. 2 No. 2 (Fall 2001) 83-100. Indiana University School of Social Work. 
possibly discuss the accomplishments of each one of the hundreds of faculty members and staff, the thousands of students, or the seemingly infinite number of academic and practice leaders and constituents who have contributed to the School and community for nearly a century. Nor could we catalog each of the significant events in its distinguished history. Rather, we attempt to capture a general sense of the origin and development of the School from three major perspectives. First, we present an historical overview of the development of the school from a small department to a large, multi-campus organization offering a full continuum of social work education, including programs leading to the Associate of Science in Human Services (ASHS), the Bachelor of Social Work (BSW), the Master of Social Work (MSW), and the Doctor of Philosophy (Ph.D.) degrees. Second, we consider the external forces and contextual factors that have influenced and shaped the School's educational and service missions in recent years. Finally, we provide a brief overview of the School today and present a vision for its future. We hope this history serves as a kind of "case study" that readers may find reflective of the evolution of social work education within the United States.

\section{Historical Review}

In establishing the Social Service Department in 1911, Indiana University declared, "There are new obligations upon the universities. They justly are called upon to help the people in all of the problems of their daily life.... Whatever knowledge is needed, whatever can aid ... must be provided to those who can use it on their problems - and problems are many" (Indiana University, 1915). Perhaps reflecting its origins as a seminary and then a small liberal arts college, Indiana University has reflected a strong service commitment throughout its history. Indeed, the University began to offer courses in social services at the turn of the $20^{\text {th }}$ century, well before the formation of the Department (Indiana University, 1920).

During the first decade of the 1900s, the Chairman of the Economics and Social Sciences Department, located in Bloomington, sought to create a laboratory context for its students-especially those who were interested in the emerging field of social work. Simultaneously, a recently appointed, highly progressive dean of the School of Medicine believed that social services could help patients recover more quickly and completely, and could aid families with psychosocial issues associated with patients' illnesses or injuries. The Dean also thought that medical students could benefit from training in social services by learning how to treat each patient in a holistic manner-as a unique person, and as a valuable member of a family and community. The mutual interests of these two academic leaders led to the formation of the Indiana University Social Service Department. For administrative purposes, the department was part of the Department of Economics and Social Sciences on the Bloomington campus. Functionally and physically, however, it was housed within the School of Medicine in Indianapolis (Indiana University, 1915; Rogers, 1983).

In establishing the department, Indiana University became the first public institution of higher learning to form an academic unit for social work education and the first in the United States to offer an advanced degree in the field (Indiana University, 1919). 
The founding director of the Indiana University Social Service Department was Dr. Edna G. Henry. The program's primary functional association was with the Medical School, which referred patients and families in need of social service to Dr. Henry, her colleagues, and students of the Department. During these early years, much of the learning was experiential in nature. Students were assigned cases and learned by providing actual social services to people in need.

The faculty of the new Social Service Department developed a coherent curriculum and taught courses such as medical social work and social medicine. They also managed a laboratory for sociology students interested in social work. In addition, they administered hospital social services and supervised community volunteers who provided aid to patients and their families.

By 1915, the Department offered a series of classroom-based courses for five general types of students. These included sociology students, medical social work students, nursing students, students interested in learning about "social conditions or social work activities; and graduate students seeking advanced work in sociological research or practical social work" (Rogers, 1983, pp. 16-17). Although students with other interests were included, medical social work constituted the primary educational focus. Students learned about the personal and social needs and problems of patients and their families, and provided services while learning through an apprenticeship model. Students addressed the common problems of the day including "alcoholism, drug addiction, epilepsy, foreigness (sic), illegitimacy, broken homes, and sex problems” (Rogers, 1983, p. 20).

Those early years engendered a sense of intellectual excitement and social meaning. Although the supply was low, the need for "trained" social workers was extremely high. The demand for educated social workers was heightened by a commonly held faith in the capacity of the academy to discover and coordinate facts that could help to ameliorate human misery and suffering. Although social work of all kinds grew rapidly throughout many sectors of society, medical social work expanded the fastest. The Social Service Department also reflected this trend through its focus on medical social work.

Following the end of World War I, tensions between the Medical School and the Department of Economics and Sociology (the name had changed in 1915), which shared overall organizational responsibility for the Social Service Department, surfaced. This was certainly understandable. They had different goals and needs. The tensions were apparently resolved in 1921 when the Department of Economics and Sociology of the College of Arts and Sciences assumed exclusive administrative responsibility for the social service program. Now known as the "Indiana University Combined Course for the Training of Social Workers," the program augmented students' liberal arts studies with professional social work training and service experience. Under this arrangement, students could complete the social work training program and earn a baccalaureate degree. Students in the program undertook the first three years of coursework on the main Indiana University campus in Bloomington, and the final (professional) year in Indianapolis, where they could undertake their field practicum courses (Indiana University, 1920). One year of graduate education in social work could also be completed in Indianapolis. In addition, social service faculty continued to teach medical and nursing students, 
administered volunteer social service activities, and guided sociology students in research and service activities.

Despite the shift in administrative authority to the Department of Economics and Sociology, the primary focus of the social service program remained medical social work, although several other courses were offered in social problems (e.g., juvenile delinquency) and social welfare policy and services (e.g., child welfare). In 1923, the program became a member of the American Association of Training Schools of Social Work. Since then, the program has continued its membership in the professional organizations that succeeded the Association, including the Council on Social Work Education (CSWE), which ultimately assumed responsibility for accreditation of programs in social work education.

By 1924, several courses were routinely offered in the social work training program at Indianapolis. These included: Theory of Social Work, Theory of Social Case Work, Field Work, Field of Social Work, Clinical Psychology, Social Psychiatry, Industrial Welfare Problems, Techniques of Social Case Work, the Family and the Community, and Research. These and related medical social work courses were offered at the School of Medicine. Over time, however, most social work courses were relocated to the Indianapolis Teaching Center in downtown Indianapolis.

By 1927, the organizational title "Social Service Department" became identified with the social services unit of University Hospitals, while the academic rubric, "The Combined Training Course in Social Work," referred to the academic program. Confusion about which department was responsible for which activities continued for decades. Although ties to the medical school were clearly loosening, many nursing students continued to enroll in social casework courses and most social work students completed their field placements through the Social Service Department of University Hospitals. However, social work faculty sought to expand the number of field placements outside the hospital setting and arranged for placements in numerous community organizations, including the Indianapolis Orphans Asylum, the Indianapolis Family Welfare Society, and Christamore House-a community service center.

In compliance with the educational standards of the American Association of Training Schools of Social Work, by 1929, the Indiana University Combined Training Course required undergraduate coursework in "sociology, economics, and psychology" (Rogers, 1983, p. 37) for admission to the program. When admitted, students were expected to complete foundation studies followed by one of five specializations: "medical social work, family social work, child welfare, visiting teaching, and public social work" (Rogers, 1983, p. 37). Students also completed field practicum experiences in agencies that supported one or more of these specializations. In addition, each student undertook a research study related to the populations served in the agency in which they were placed.

By 1930, the University had established a Bureau of Social Research at Indianapolis in association with the social work program. The Bureau conducted several research studies related to topics such as unemployment, distribution of felonies, mortality rates, and juvenile court statistics. These studies complemented students' educational and professional experiences. 
In 1931-32, the Combined Training Course for Social Work was reorganized as a two-year graduate program in Indianapolis. Interested in promoting social work as a profession, faculty promoted graduate social work education. Leading to the master's degree, the program provided coursework for three specializations, including social casework, public welfare administration, and social statistics (Indiana University, 1936-37). Students completed a research thesis and oral examination in addition to classroom and field practicum experiences.

In 1935, during the Great Depression, the Combined Training Course for Social Work became a division within the Department of Sociology. The new Division shifted its curriculum focus to the preparation of social workers for service to the vast number of unemployed persons who had found their way into the rapidly growing public welfare programs.

World War II introduced a whole new set of challenges for the Division as the need for professionally trained social workers increased dramatically. The Division introduced a three-semester year in order to train graduate-level social workers more quickly. Perhaps related to wartime needs and activities, interest in baccalaureate social work education grew nationally and locally. In 1942, a baccalaureate program with a major in social service was inaugurated on the Bloomington campus. In 1944, the Indiana University Board of Trustees established the Division of Social Services as a unit within the College of Arts and Sciences, separate from the Department of Sociology. Physically, the Division remained in Indianapolis and provided professional education leading to the degree of Master of Arts in Social Service and continued to collaborate with the College in offering an undergraduate major in social service on the Bloomington campus (Indiana University, 1945-46). Requiring 45 credit hours, the new master's curriculum offered four distinct concentrations: casework, community organization, administration, and group work (Indiana University, 1944-45).

In 1945, Dr. Grace Browning, a nationally regarded social work educator from the University of Chicago School of Social Service and author of several books on public and family welfare, joined Indiana University to head up the Division. She directed both the graduate program in Indianapolis and the undergraduate courses in Bloomington. By this time, accredited social work programs were required to address eight basic curriculum areas and, in addition, provide more advanced classes and field work in an area of specialization. The eight basic areas included "social work administration, social casework, social group work, community organization, social research, medical information, public welfare information, and psychiatric information" (Rogers, 1983, p. 57).

By 1946, five faculty members were located on the Indianapolis campus and two at Bloomington. There were 20 full-time and 30 part-time students in the graduate program. Field placements expanded considerably to include "the Family Welfare Association, the Indianapolis Children's Bureau, the Catholic Charities Bureau, the Social Service Department of the Indianapolis Public Schools, the Indianapolis Public Health Center, the Jewish Family Service Association, Flanner House, and the Morgan Department of Public Welfare" (Rogers, 1983, p. 62). By 1948, 79 fulltime students were enrolled in the Indianapolis graduate program. 
During the late 1940s, the Division's graduate curriculum expanded to a minimum of 60 credit hours in professional coursework. These included courses in human behavior in the social environment, social welfare policy and organizations, research, social work practice, and field practicum. That curriculum emphasized social casework. However, in 1950-51, the Division added social group work as a second concentration. In addition, a course in community organization was required.

Upon Dr. Browning's death in 1951, Professor Mary Houk was appointed Director of the Division. During the 15 years that she served in that position, she transformed the small division into a nationally and internationally renowned professional school. She was remarkably successful in securing educational grants from local, state, and federal sources and in attracting highly qualified faculty and students. Primarily because of her success in enhancing the program's reputation, in 1966, the Board of Trustees upgraded the status of the Division by creating the Graduate School of Social Service. Director Houk was appointed Dean of the School and students earned the Master of Social Work degree.

Following Dean Houk's retirement in 1966, Professor Walter Johnson became Acting Dean of the School, while a national search for a new Dean took place. During his short tenure, Acting Dean Johnson was able to obtain a commitment from university officials to move the School from its long time location to a building planned for construction on the new campus of Indiana UniversityIndianapolis.

In 1967, Dr. Richard Lawrence became the second Dean of the School. Approximately 115 full-time and 18 part-time students were enrolled in the graduate program at that time. Dr. Lawrence served as Dean for nine-years-overseeing the School during the turbulent years of the 1960s and early '70s.

During this period, the MSW curriculum was reorganized. As a participant in a national curriculum project, the School attempted to cross-integrate its coursework content by organizing plenary sessions and discussion groups instead of traditional classes. By 1969-70, block field practicum placements were introduced for the first time and a community organization concentration complemented those in social casework and social group work.

In 1969, the School reorganized its undergraduate social work curriculum. Building upon the programs that had been offered on the Bloomington campus for many decades, undergraduate social work education returned to Indianapolis as well. During the early 1970s, the professionalization of baccalaureate social work was a major topic within social work academic and professional circles. Faculty of the School embarked on a significant process of curriculum review that led to the conceptualization of a continuum for social work education (Indiana University School of Social Service, 1974a). The envisioned continuum included four levels of education for social work, including programs leading to the associate, baccalaureate, masters, and doctoral degrees. Each level would reflect its own educational cohesion and integrity, would be more complex than the previous level, and would be progressively linked to the next level in an ascending order of complexity. 
In 1971-72, the School moved from its long-time home in the Indianapolis Teaching Center to the fifth floor of Cavanaugh Hall on the growing Indianapolis campus of Indiana University. Subsequently, this modern, urban campus emerged as Indiana University-Purdue University Indianapolis (IUPUI), as programs from the two universities were physically merged. Two years later, the School of Social Service was renamed the Indiana University School of Social Work to emphasize its full identification with the social work profession.

During the 1970s, Indiana University expanded its campuses throughout the state. The School, with programs on both the Indianapolis and Bloomington campuses, was encouraged to promote social work education-especially at the graduate level—on the emerging "regional" campuses. Faculty members committed to extending access to social work education engaged in numerous efforts to offer courses and develop programs. One faculty member was assigned to develop graduate courses on the Indiana University Northwest (Gary) campus. Courses were also developed for television delivery to the Ft. Wayne and South Bend campuses. In addition, block field placements were developed in communities outside of the Indianapolis area so that students could complete their internships in closer proximity to their homes. Class schedules were redesigned to accommodate students who resided outside the Indianapolis area (Rogers, 1983, p. 103).

In 1972, the School proposed new curricular designs for the School's new Bachelor of Social Work (BSW) and the Associate of Science in Human Services (ASHS) programs. In 1973, the proposal was approved by Indiana University and the Indiana Commission for Higher Education (ICHE). In order to accommodate the two new undergraduate programs, "Graduate" was dropped from the School's name to encompass the expanding continuum of social work education at Indiana University.

The School's two-year ASHS program enabled students, especially nontraditional students, to develop basic competencies for the provision of human services either as part of a service team or as an independent practitioner when intervention at a more complex level was not required (Indiana University School of Social Service, 1974c). In 1975, the ASHS program was inaugurated on the Indiana University East (Richmond) campus. Subsequently, a full BSW program was implemented, enabling undergraduate students from the central-eastern portion of the state to enroll in associate or baccalaureate programs.

The School's new BSW curriculum was designed to prepare students for beginning professional social work practice with a focus on the problem-solving process. Over several years, this curriculum was also fully implemented on the Indianapolis, Richmond, and Bloomington campuses, replacing the undergraduate social service program that had been offered for so many decades in cooperation with the College of Arts and Sciences in Bloomington.

The BSW curriculum required students to complete general education and supportive courses from the arts, physical sciences, and the social and behavioral sciences in addition to social work courses. The social work course areas included: human behavior in the social environment, social welfare policy and services, research, social work practice, and field practicum. The BSW program was initially accredited by CSWE in 1976 and has been continuously accredited ever since. 
The professionalization of baccalaureate education significantly affected the master's program. During 1973-1976, the School substantially revised its MSW curriculum. Two central concepts, generalist practice and social systems, significantly influenced the first (foundation) year of the curriculum. Within the advanced year, the long-valued casework and group-work tracks were integrated into an "Interpersonal Practice" concentration intended to prepare students for "direct clinical practice with the individual, the family, and the small group" (Rogers, 1983, p. 100).

The Planning and Management (P\&M) concentration curriculum evolved during the late 1970s. Both concentrations allowed for secondary emphases in selected fields of service-family and child welfare, corrections, mental and physical health, and school social work-fields that reflected the prevailing interests of faculty and students.

Furthermore, the concentrations incorporated new and invigorating courses on topics such as Race, Poverty, Probation, and Corrections (Rogers, 1983). An affirmative action policy was written and adopted by the faculty in the spring of 1973. Special efforts were made to recruit African-American faculty and students, leading to greater diversity within the school.

Widespread interest in social work education continued to heighten during the 1970s. Responding to requests from agencies, legislators, prospective students, and other constituents, the Indiana University President appointed a committee to examine the statewide needs for graduate social work education. The University's Administrative Committee and Board of Trustees endorsed the Committee's recommendation that the School of Social Service extend graduate social work education throughout the state. Graduate courses continued on the Indiana University Northwest (Gary) and Indiana University South Bend campuses. New courses were offered at Indiana University East (Richmond) as well as on the Columbus, Ft. Wayne, and New Albany campuses. In the mid-1970s, the School in cooperation with the University of Evansville, designed and offered a program of part-time graduate coursework. Over a period of four semesters, students could earn as many as 45 semester credit hours in Evansville. Students were then expected to complete 12 months of full-time study in Indianapolis to qualify for the MSW degree (Rogers, 1983, pp. 106-107).

Interest in developing a doctoral program at Indiana University School of Social Work originated during Dean Lawrence's administration. Even as preparations were being completed for the initial accreditation of the BSW program in 1974, the faculty were discussing a larger vision for the School that would eventually encompass the full range of educational programs, including degrees at the associate, baccalaureate, masters, and eventually doctoral levels. By 1970, Indiana was the only state in Federal Region V (including Illinois, Indiana, Minnesota, Michigan, Ohio, and Wisconsin) that did not have at least one doctoral program. Consequently, Hoosiers who wished to pursue a doctoral degree had to leave the state to do so. As the only school of social work in the State of Indiana approved by the Commission on Higher Education to provide graduate education, it was apparent to faculty that if doctoral education was ever to flourish within the state, Indiana University was the obvious venue for it to take root. 
In 1977, Dr. Lawrence stepped down as Dean to return to teaching and research. Dr. Leonard Schneiderman was named Dean and Dr. Cyrus Behroozi was appointed first Associate Dean of the School. During the five years Dr. Schneiderman served as Dean, the academic credentials of the faculty began to shift from one predominantly comprised of highly experienced masters' level practitioners to one that required doctoral-level education as a condition of tenure track appointment. Dean Schneiderman employed several additional faculty-most of whom had earned or were about to complete their doctoral degrees. He also dramatically increased the amount of external funding.

Dean Schneiderman identified the creation of a doctoral program as one of the school's highest priorities. Schneiderman was convinced that the realization of the school's aspirations for national prominence would inevitably require the development of a research infrastructure that could lead to the creation of new knowledge. It was apparent that the schools of social work that had attained this rarified status were schools that had gained reputations for being on the cutting edge of knowledge development. While they varied with respect to their affiliation with public or private universities, all of them had well-established doctoral programs with many having also developed related research centers. If the School was to join this elite group, Schneiderman believed it would have to expand its mission to include not only the dissemination of existing knowledge, but also the creation of new knowledge.

During 1978-82, the School refined the practice focus of its BSW curriculum as generalist social work. Furthermore, the School revised its MSW curriculum to emphasize generalist content within the first semester and began the MSW concentration coursework in the second semester of the first year curriculum.

The School's statewide mission was reinforced in 1979 and 1980 with the submission of a Program Improvement Proposal to the Indiana Commission on Higher Education to extend graduate social work education to campuses in Gary, South Bend, Ft. Wayne, and Evansville. The Commission authorized the School to award the MSW degree at these campuses. However, funding did not accompany the approval and efforts to develop "off-campus" programs were impeded due to the enormous resource requirements (Rogers, 1983, pp. 122-123).

In 1979, a faculty-planning group was formed at the School to consider feasibility issues and prepare a formal proposal for a doctoral program that it hoped eventually would be approved by the Indiana Commission for Higher Education. It also struggled with the question of whether the program should be developed primarily with a practice focus and a DSW degree awarded through the School of Social Work, or whether it should emphasize research and be offered as a Ph.D. awarded through the Graduate School. This issue was ultimately resolved at the University level when it was determined that the School did not yet possess the requisite research infrastructure necessary to support the kinds of research required of a Ph.D. program.

Despite unanimous approval and enthusiastic support at all levels of the University, including the Board of Trustees, the ICHE tabled the proposal in 1980 pending "a report on the progress of the expansion of the MSW program" to three 
additional Indiana University campuses and the University of Southern Indiana (ICHE, 1990). One year later, the Commission voted by the narrowest of margins (seven to six) against approval.

In 1981, the School relocated from Cavanaugh Hall to the fourth floor of the brand new Education-Social Work Building. A year later, Dr. Schneiderman resigned his position as Dean. Dr. Beulah Compton, a graduate of Indiana University School of Social Service and co-author of a leading social work textbook, served as Acting Dean for a year followed by Dr. Gerald Powers, who served as Acting Dean until 1984, when Dr. Sheldon Siegel was appointed Dean of the School.

Initiated by Dr. Schneiderman and sustained by Dr. Siegel, the School made a concerted effort to increase the diversity of both its faculty and student body. Dr. Schneiderman was responsible for developing the School's affiliation with the Council on International Programs (CIP), an international initiative that has, during the intervening years, been instrumental in bringing literally hundreds of human service professionals from more than 80 countries around the world to the IUPUI campus. This international and interdisciplinary initiative was sustained by Dr. Siegel under the direct leadership of Professor David Metzger.

In a further effort to enhance statewide access to graduate social work education, the School initiated a part-time Weekend Work-Study Program on the Indianapolis campus. Initially, the program was limited to applicants currently employed in social service positions living outside the Indianapolis area. Students completed the master's foundation curriculum in 15 months by taking classroom courses on Saturdays and completing the first field practicum in their place of employment. Work-study placements could be arranged in the student's workplace provided the practicum experience was distinctly different from their regular work responsibilities and a different supervisor could be provided. This program proved to be extremely popular and precipitated large numbers of admission applications.

Despite the absence of additional funding, through the work-study program, the School found a means to enhance access to graduate social work education to students throughout the state. The program was a resounding success and led to the establishment of part-time evening, part-time day, and part-time Saturday programs. The long-established Advanced-Standing Program also enabled qualified BSW graduates to complete the MSW program at an accelerated pace.

In the late 1980s, Dean Siegel reconvened a group of faculty to consider the feasibility of submitting a new proposal for a doctoral degree program. In the years that intervened since submission of the original proposal, the makeup of the faculty had changed significantly, both in terms of its academic credentials and its racial diversity. All new faculty appointments were required to have attained a doctoral degree with an identified research agenda. It was evident by this point that the scholarly productivity and research potential of the faculty had increased dramatically. Attributable in part to these changes, in 1991 the faculty reaffirmed its commitment to the development of a doctoral program and decided that this time the School should submit a proposal for a Ph.D. program with a strong research 
emphasis. Again, the proposal enjoyed unanimous support at all levels of the University review process. It was submitted to the ICHE for review in the fall of 1992 and was finally approved by the Commission in June, 1993. The School was approved to accept its first class of doctoral students following formal accreditation by the North Central Association of Colleges and Schools in 1994. The first cohort of six students entered the program the following fall and four years later the School graduated its first doctoral candidate.

The format for the doctoral program was built around a flexible interdisciplinary model that included an intentionally integrated series of didactic and experiential learning opportunities. While grounded in the historical and ideological commitments of the social work profession, the program was designed to take full advantage of the relevant human service professions and related academic disciplines available throughout the University. As such, it was designed to enable students to tie their research interests to related areas, such as education, public and environmental affairs, sociology, psychology, women's studies, philanthropy, or law. Given its strong multi-disciplinary thrust, the program was built around a "committee approach" to advising that would intentionally draw upon the professional expertise of scholars throughout the University whose intellectual and research interests paralleled those of the students who were to be enrolled in the program.

During the early 1990s, despite the success of the part-time MSW programs on the Indianapolis campus, interest in graduate social work education once again arose on several other Indiana University campuses. Given the historical context, the School could not expect to receive funding to establish MSW programs on the regional campuses. However, the School emphasized to university and campus leaders its desire to help those campuses mount MSW programs provided they generated the funding to house the program, employ necessary faculty and staff, and deliver the educational services.

Since there was only one School of Social Work at Indiana University (headquartered in Indianapolis), programs on other campuses would (according to CSWE policies) be considered branches. The School, based on its accredited status, provided the curriculum, faculty development, and academic supervision while the campuses provided the funding and earned the income associated with student enrollment. Under these arrangements and based on fairly complicated memoranda of understanding, full MSW programs were initiated on the Indiana University South Bend and the Indiana University Northwest (Gary) campuses during 1992-1995. These programs were modeled after the part-time programs that had become such a success in Indianapolis.

As these programs became increasingly recognized and an MSW program received CSWE accreditation at the University of Southern Indiana, the demand for the Weekend Work-Study Program became more manageable. Prospective students could now enroll in MSW programs closer to their homes and workplaces. In light of these developments and the existence of more than a dozen accredited BSW programs throughout the state, the School was in a position to conclude that it finally realized its long-held goal of providing professional social work education throughout the State of Indiana. 
In 1994, Dr. Roberta Greene became the School's fifth Dean. One of her first actions was to create two new positions at the School. Dr. Barry R. Cournoyer was appointed Associate Dean for Quality Improvement and Dr. Irene Queiro-Tajalli became the School's Associate Dean for Systems.

During her five-year tenure, Dr. Greene built upon her predecessors' efforts to develop a variety of community-based field units headed by teacher/practitioners (i.e., non-tenure-track faculty members physically located in agency-based field settings). Tied to a range of critical service delivery areas (e.g., mental health, housing, child welfare, youth development, school social work, and neighborhood centers), these field units not only provided dynamic in vivo settings for collaborative student learning, but also viable laboratories for a wide range of practice-sensitive research. Dean Greene also secured major funding that dramatically enhanced the computer and technological resources of the School, and contributed to a growing interest in and capacity for research among social work faculty and students.

\section{External Forces Shaping the School's Mission: 1960-2000}

The election of John F. Kennedy as President of the United States generated great optimism that the 1960s might be a decade when major social problems from child welfare to crime and poverty would be addressed and ultimately resolved. Indeed, the civil rights, students', women's, and, of course, the anti-war movements challenged the status quo. Interestingly, much of the social work community-from students and faculty to the professional associations-were noticeably passive during this major social revolution. It would be some time before substantial numbers of social workers would become socially active-often in the form of advocacy for the rights of women and people of color.

During the 1970s, federal legislation, including shifts in public assistance to dependent children of unmarried, abandoned, or divorced women, offered new opportunities as well as challenges for social policy and social work practice. Title XX of the Social Security Act provided funds directly to the states for social welfare service. In 1979, the Indiana General Assembly adopted a new Juvenile Code that provided training for child welfare workers. These initiatives in federal and state policy, while applauded, would later be seen as reflecting the initial indications of a more conservative political approach. The reliance on local and state authority, and the private market for implementation, plus the notion of cost and service accountability, were clarion calls for what was to come in the 1980s. The optimism driving change during the '70s would not be sustained for long.

Throughout its history, the School had provided substantial amounts of service to the larger civic and professional communities of the state. During the 1970s, faculty and students became even more active and provided consultation, direct and indirect services, research, and leadership support to numerous constituencies and agencies. In several instances, these efforts contributed to the development of organizations and programs that later became core agencies providing services to children, families, and communities statewide (see Children's Bureau, 2000).

As the decade of the ' 80 s began, the renewed conservatism and the politics of the New Federalism led to further retrenchment in the role of government and shifts in the auspice of social services. During the presidency of Ronald Reagan, many 
social workers struggled to challenge or adjust to changes in the nature, organization, and funding of social services. The Reagan domestic policy focused on three basic objectives: transfer responsibility and authority from the federal government to state and local communities; rely upon the private sector to provide for social services; and reduce federal programs and spending for social welfare initiatives (Segal \& Brzuzy, 1998). Each of these initiatives provided fodder for debate and retrenchment in Indiana's already conservative and residual approach to social welfare.

Early in 1980, Dean Schneiderman encouraged faculty and students to further increase the school's involvement with the professional and general communities of the state. The creation of the Indiana Coalition for Human Services (ICHS) became one of those initiatives (ICHS, 1981). Members of the Indiana University School of Social Work community and other professionals convened to consider the implications of legislative policies emanating from the new Reagan administration in terms of their impact on the delivery of social services in Indiana.

The state had little recent history in the design and implementation of social services at the local level. In Indiana, public welfare was administered by 92 different county departments and some 1,000 township trustees. Social service managers were accustomed to reacting and appealing directly for programs and funding from a cafeteria of categorical federal programs administered by various agencies in Washington, D.C. State government was not organized in a way that fostered or maintained communication or leadership among public social services providers.

The Indiana Coalition for Human Services was formed during the summer of 1982. There were 24 founding member organizations from throughout the state, and the Dean of the School of Social Work was elected its first President (ICHS, 1982). The purpose of the ICHS was twofold: (1) educate and prepare state and local leadership for the transformation from federal categorical allocations for social services to block-grant provisions and authority at the state and local level, and (2) coordinate statewide advocacy efforts for social welfare policy at the legislative level. A graduate of the School, employed by this new coalition as a professional lobbyist, gradually gained the respect and trust of legislators and state officials as an authority on social policy and social services.

During the 1980s the proportion of initiatives introduced into the Indiana General Assembly focusing on social services and social work increased from fewer than $20 \%$ to more than one-half. Faculty served on the ICHS board and its committees, while students pursued related field placements and learned to practice in the legislative and policy analysis arena.

Opportunities for collaboration with professional colleagues and service providers throughout the state became commonplace, and professors and students' efforts yielded noticeable results. For example, as a direct result of the scholarly and advocacy work of two of the School's professors, a State Commission on Abused and Neglected Children and Their Families was established. Chaired and staffed by the School of Social Work, the Commission's work resulted in legislation that greatly improved the child welfare system in Indiana. Another of the School's professors' scholarly and service work led directly to the establishment of an office 
of Community Services in the Indianapolis Department of Public Housing. Second-year students in the planning and management concentration of the graduate program found creative field placements in areas of social policy analysis, information systems analysis, funding and resource development, and social service program design. The visibility and respect for the profession of social work and social work education in Indiana made significant strides during this period.

\section{Social Work Licensing}

For many years the National Association of Social Workers (NASW) and its Indiana Chapter fought valiantly to secure legal regulation for the social work profession. Two of the School's professors chaired the Indiana NASW Committee on Legal Regulation and were tireless in their pursuit of social work certification. During the 1987, 1988, and 1989 legislative sessions of the Indiana General Assembly, bills providing for social work certification were introduced and passed in one house; only to be denied passage in the other. The ICHS and many of its member agencies provided funds to employ a full-time lobbyist during the 1989, 1990, and 1991 legislative sessions. Passage finally came late during the 1991 legislative session, but not without substantial compromise.

Social workers across the state were overjoyed to learn of the passage of this hard fought legislative victory. For several years Indiana had remained the only state in the nation without some form of social work regulation. However, the celebration was short-lived. Two days following adjournment of the General Assembly, the Director of the Indiana Chapter of the National Association of Social Workers and a professor from the School of Social Work were summoned by the Governor's administrative assistant and advised that Governor Evan Bayh had vetoed the legislation.

Rushed to meet the constitutional deadline for submitting signed legislation to the Secretary of State's Office, the Governor had vetoed the bill believing it provided only for the certification of Marriage and Family Counselors and excluded social workers. Unaware of last-minute negotiations that led to the inclusion of Social Workers in the bill, the Governor acted on earlier advice not to support the legal certification of this group. Following a morning of meetings with the governor and his staff, an unusual agreement was forged whereby the Governor would support a legislative resolution to override his own veto at the annual one-day legislative session in the autumn. Although formal celebration of the legislative victory was delayed another six months, the decade-long aspiration to secure social work certification had finally been realized.

\section{An International Perspective}

In an effort to increase awareness and respect for racial, ethnic, and cultural diversity and global understanding, Indiana University School of Social Work began to develop field practicum outside the United States during the mid-1970s. In 1976, the Dean negotiated placements for students in London. Over the next 10 years, similar practicums were developed in Puerto Rico, Montreal, the Bahamas, Germany, and Brazil. By 1982, communications with the Fachhochschule (faculties of social work) in Hamburg, Germany resulted in an agreement to offer graduate-level courses and a field practicum to German students (Indiana University 
School of Social Work and Fachhochschule Esslingen-Hochschule fur Sozialwesen, 1996). Support for this international study program came from the German Education and Cultural Foundation. Each year, some six-to-nine German social work students completed MSW courses on the Indianapolis campus and undertook community-based field practicums alongside their Indiana University colleagues.

Efforts to broaden the range of opportunities for cross-cultural and international experiences for faculty and students led to the School's admission to the Council of International Programs (CIP). The CIP was one of the cultural and educational programs of the United States Department of State created in 1955 as part of the Fulbright educational exchange programs. The Indiana University School of Social Work became a CIP university affiliate in the summer of 1978. For 19 years the school participated in this cultural exchange program referred to locally as the IUCIP (Metzger, 1997).

Three core objectives shaped the program: (1) host family living, (2) an internship in practice settings that paralleled participants' prior education and experience, and (3) cross-cultural seminars and workshops covering social work education and practice, and family life traditions and institutions. Professor David Metzger was appointed to direct the program. A 15-member advisory council comprised of social work faculty, social service agency representatives, and public officials was appointed to assist in gaining financial resources, recruiting host families, and supporting the program. Eleven participants from 10 nations came to the school in April of 1979 to begin the first program.

Nineteen years later, 284 individuals representing 79 nations had participated in this educational and cultural exchange program, and are now identified as IU-CIP alumni. The program enhanced the School's global perspective and enriched the personal and professional lives of everyone involved. During these 19 years, social workers, health specialists, physicians, lawyers, teachers, and elected officials from every part of the globe joined with the school's students and faculty in classes, workshops, field trips, and social gatherings. Many collaborated with faculty from the School of Social Work and other university departments, and with community professionals on research projects and overseas study opportunities.

The participants reflected an incredible range of cultural diversity and their professional credentials were exceptional. For example, among the IU-CIP participants were a psychiatrist who happened to be the daughter of the President of Hungary; an elected member of the Parliament of Rumania; a principal of the School of Social Work in Lahore, Pakistan; a Sister of the Order of Providence teaching in a rural area in the Southern Philippines; and a non-conventional Probation Officer from Austria. More than 200 families shared their lives with these professional colleagues in ways only possible through host living. Hundreds of social workers, lawyers, teachers, and health care professionals examined practice, policy, ethical, social, political, economic, and philosophical issues with these international colleagues through unique learning experiences. Needless to say, the nature and depth of these learning experiences were extraordinary, intellectually exhilarating, and often transcendent. These 19 years provided opportunities for learning and experience never expected or even imagined. Profoundly touched by the 
experience, faculty, students, hosts, and colleagues throughout the state were forever changed, yet hard-put to tell others how or why.

The impact of the IU-CIP program on Indiana University School of Social Work, its faculty and students, and the university's global educational mission is difficult to overstate. Although the School hosted its last cohort of CIP participants in 1997, the program's legacy continues to resonate in many activities. For example, in 1996, 21 students and three faculty members of the School were invited to a twoweek long series of workshops and seminars in German-American Social Policy and Social Work Practice at the Fachhochschule at Esslingen University in Southern Germany (Indiana University School of Social Work and Fachhochschule Esslingen-Hochschule fur Sozialwesen, 1996). This was the school's first experience in facilitating a large cohort of students and faculty on such a mission. This event opened doors of opportunity for education, practice, and research still to be developed. Similarly, an MSW graduate of Indiana University School of Social Work currently serves as the Director of the International Center of Indianapolis and continues to coordinate special projects that bring professionals from throughout the world to the city and the university for cultural and educational enrichment experiences. Such international activities maintain the rich and enriching legacy of the IU-CIP program.

\section{The School of Social Work: A Contemporary Overview and Vision for the Future}

Currently, Indiana University School of Social Work offers a full continuum of social work education from the associate to doctoral levels. Nearly 900 students study social work on several Indiana University campuses. The two-year, Associate of Science in Human Services program is offered on the Richmond campus. The Bachelor of Social Work (BSW) program is a 51-credit hour program of study designed to prepare students for beginning generalist social work practice. Full BSW programs are offered on the Indianapolis, Bloomington, and Richmond campuses. The Master of Social Work (MSW) program is a 60-credit hour program designed to prepare students for advanced professional practice in one of two concentrations: Interpersonal Social Work Practice or Macro Social Work Practice. Interpersonal practice refers to direct work with individuals, families, and small groups in need of social services. Macro practice refers to macro system service through policy analysis, advocacy, community organization, planning, or administration. Complete MSW programs are offered on the Indianapolis, Gary, and South Bend campuses. The social work doctoral program (Ph.D.) is a 90-credit hour research-oriented program designed to prepare graduates for leadership positions within the profession.

The kinds of intellectual and methodological skills developed as part of a research-focused doctoral program are critical to the profession's continuing efforts to extend and improve the overall quality of its knowledge base, including its ability to effectively address individual and societal problems, to serve as active participants in shaping public policy, and to meaningfully engage in the process of preventing and ameliorating social and economic injustice. In order to complement and extend this vision, two additional knowledge-building initiatives were introduced. In 1999, the School sponsored the creation of its own scholarly journal Advances in Social Work: Linking Research, Education, and Practice. In 2001, the 
Office of Research Services was established. Both of these initiatives were designed to strengthen the research infrastructure of the School, the former by providing a vehicle for the dissemination of new knowledge, and the latter by serving as a catalyst in developing a research culture that is supportive, encouraging, and collaborative in nature. It is believed that the synergistic effect generated by a viable doctoral program, a professional journal, and an office for the coordination of research services will contribute substantially to the overall intellectual climate of the School. By increasing opportunities for faculty and students to engage in collaborative practice-sensitive and applied research, the School has positioned itself to foster interdisciplinary knowledge-building projects with colleagues of like mind both within and outside the University.

In 2000, Dr. Michael Patchner became the $6^{\text {th }}$ Dean of Indiana University School of Social Work. He aspires to build upon the foundations laid by his predecessors to improve the quality of the School's educational, service, and research activities. Dean Patchner hopes to continue efforts to provide high quality educational programs with curricula that are current and relevant, recruit students who seek to serve and yearn for challenging educational experiences, and to provide an educational environment that is diverse and representative of its state, national, and international constituencies. Dr. Patchner anticipates the development of jointacademic programs, especially at the masters' level (Patchner, 2000).

Research and scholarship will have a higher priority to better complement the School's historical emphasis upon teaching and service. The School aims to become a national leader in the assessment of educational processes and outcomes. Drawing upon the most recent Educational Policy and Accreditation Standards (Council on Social Work Education, 2001) as a catalyst for change, the School has committed to curricular innovation that will identify it nationally as a leader in learner-focused, outcome-based education (Patchner, 2000).

In conclusion, the history of social work education is much more than the history of an academic discipline. As such, "it is a significant part of the historical development of American society ... marked by economic and societal changes-leading to resolution of some social problems and creation of new problems" (Austin, 1986, p. 46). We believe that this brief depiction of the evolution of the Indiana University School of Social Work mirrors in many respects the experiences of other schools and departments of social work, and as such may be enlightening to those interested in the history of social work education.

\section{References}

Austin, D.M. (1986). A history of social work education. Austin, TX: The University of Texas School of Social Work.

Council on Social Work Education. (2001). Educational policy and accreditation standards. Washington, DC: Author.

Children's Bureau. (2000). For the children's sake: A history of the Children's Bureau of Indianapolis: 1851 to 2001. Indianapolis: Author.

Indiana Coalition for Human Services [ICHS]. (1981, October). Minutes of the Board of Directors Meeting. Indianapolis: Author. 
Indiana Coalition for Human Services [ICHS]. (1982, Summer). Minutes of the Board of Directors Meeting. Indianapolis: Author.

Indiana Commission on Higher Education (September, 1990). Minutes of the ICHE. Indianapolis, IN: Author. Indiana University (1915). Indiana University Newsletter, 3(8). Bloomington, IN: Author.

Indiana University (1919). Indiana University Newsletter, 7(10). Bloomington, IN: Author.

Indiana University (1920). Indiana University Newsletter, 8(7). Bloomington, IN: Author.

Indiana University (1936-37). The Training Course for Social Work. Bloomington, IN: Author.

Indiana University (1944-45). The Training Course for Social Work. Bloomington: The University.

Indiana University (1945-46). Division of Social Service Bulletin 1. Bloomington, IN: Author.

Indiana University School of Social Service (1974c). Report to the CSWE Commission on Accreditation. Vol. II. Indianapolis: Author.

Indiana University School of Social Service. (1974a). A continuum for social work education. Indianapolis: Author.

Indiana University School of Social Work and Fachhochschule Esslingen-Hochschule fur Sozialwesen. (1996). An exchange visit. Indianapolis: Author.

Levy, C.S. (1968). Social work education and practice: 1898-1955. New York: Wurzweiler School of Social Work, Yeshiva University.

Metzger, D. (1997, January 12). IU-CIP: Its past and future. Memorandum to the Indiana University School of Social Work Committee on International Affairs. Indianapolis: Indiana University School of Social Work.

Patchner, M. (2000, September). Presentation to the Faculty Senate of Indiana University School of Social Work. Indianapolis: Indiana University School of Social Work.

Rogers, H.C. (1983). Seventy years of social work education at Indiana University. Indianapolis, IN: Indiana University.

Segal, E.A., \& Brzuzy, S. (1998). Social welfare policy, programs, and practice. Itasca, IL: F. E. Peacock.

Task Force on Social Work Research (1991) Building social work knowledge for effective services and policies... A plan for research development. Austin, TX: The University of Texas School of Social Work.

\section{Author's Note:}

Address correspondence to: Barry R. Cournoyer, D.S.W., Indiana University School of Social Work, 902 West New York Street, Indianapolis, IN 46202-5156 USA, bcourno@iupui.edu. 